\title{
Coursebook Development and Evaluation for English for General Purposes Course
}

\author{
Mohammad Zohrabi (Corresponding author) \\ Department of English Language \\ Faculty of LiteratureThe University of Tabriz, Tabriz, Iran \\ E-mail: mohammadzohrabi@gmail.com
}

Received: September 15, $2010 \quad$ Accepted: September 28, $2010 \quad$ doi:10.5539/elt.v4n2p213

\begin{abstract}
Writing a coursebook is a demanding task and more important than writing is how to evaluate it in order to pin point its weaknesses and improve them. If we yearn to produce a quality and useful coursebook, we need to consider how to develop and evaluate it. The study reported in this article describes the process in which the researcher developed and evaluated a coursebook (Reading English in Action) for the English for General Purposes (EGP) course at the University of Tabriz, Iran. In order to investigate this coursebook's virtues and weaknesses, the researcher taught it for four semesters and asked six of his colleagues to use it for their EGP courses. A questionnaire was developed based on a checklist that had been prepared by the researcher and distributed to the six language professors who taught the coursebook and 480 students who studied it for one semester. A semi-structured interview was conducted with the six professors and twenty four students. The aim was to carry out in-use and post-use coursebook evaluation because these are more valid and reliable than pre-use one. Since the objective of the EGP course was to develop the students' reading skill and strategies, the present coursebook was written to fulfill these goals. However, the results of the study depicts that mere emphasis on reading bores the students and they require more interactive communicative use of the language. This study can provide invaluable insights for material writers, curriculum developers, and language teachers.
\end{abstract}

Keywords: Coursebook writing and evaluation, English for general purposes (EGP)

\section{Introduction}

It is quite ideal and optimal for each teacher to be able to write a coursebook for his/her course. Although the process of writing and publishing is demanding and challenging, it is certainly worth the effort. It is because developing a coursebook is a lifelong experience and makes teachers to develop professionally (Masuhara, 2006). This article reports on the coursebook (Reading English in Action) which was written and evaluated by the researcher. The reason that this coursebook was developed was that there were numerous books available at the market but each one had their own shortcomings. Therefore, since the researcher had taught the EGP course at the University of Tabriz for more than twelve years, it was decided to develop a coursebook based on the EGP (English for General Purposes) course's objectives. However, after using the coursebook for four semesters, it was realized that there were some conflicts between the course's and students' goals. The EGP course was intended to develop the students' reading skill and strategies. It was aimed to prepare the students to tackle their discipline's requirements. Meanwhile, the EGP course was aimed to prepare the students to deal with their educational and occupational needs. However, the study reveals that most of the students prefer more communicative activities and tasks. They want to interact in English language and produce language as far as they receive it.

More importantly, it was experienced that both writing and publishing a coursebook takes a lot of time. However, if we want to do something worthwhile, we need to spend some time on it. The more demanding part of producing the present coursebook was to find a publisher to publish it. It is because most of the publishers were concerned with their investment and required guarantee for the return of their money and plus its benefits. So, in order to satisfy the publisher, the researcher asked six of his colleagues to use this coursebook (Reading English in Action) in their EGP classes. Fortunately, in the first printing, three thousands and in the second impression another three thousands were published and sold.

\section{Review of Literature}

\subsection{The Role of Coursebook}

Since English is a foreign not a second language in Iran, classroom serves as the main source of exposure to English for students. Therefore, materials, especially coursebooks play a vital role in exposing the students to the English 
language (Dudley-Evans \& St John, 2000, p. 171). This implies that it is the coursebook which determines the classroom activities, influences teachers' teaching methods, and the students' roles. It should be mentioned that the main material which is used in undergraduate courses in Iranian universities is the coursebook. As Richards (2007, p. 251) maintains, materials provide the main input for the students and the type of the "language practice that occurs in the classroom." Nunan $(1999$, p. 98) believes that coursebook is the main element of any curriculum and "it is difficult to imagine a class without books ..." It is the coursebook which enhances the learning process by mediating between the teachers and students and "offers a coherent syllabus, satisfactory language control ..." (Harmer, 2002, p. 304). Although materials do not usually represent the actual process of teaching, they "represent plans for teaching" (Richards, 2007, p. 270). In this regard, Robinson (1991, p. 57) argues that coursebooks provide "a framework for a course, forming in essence a syllabus." Meanwhile, she maintains that using a coursebook has positive psychological effects on the students because coursebooks provide the whole semester's course to them. At this juncture, Hedge $(2002$, p. 358) states that when we choose a coursebook, we, in fact, choose a "planned sequence of items to be taught." In this regards, Dudley-Evans and St John (2000, p. 170) offer four main reasons for using materials in the classroom: "as a source of language, as a learning support, for motivation and stimulation, and for reference." Cunningsworth (1995, p. 7) believes that coursebooks have multiple roles in English language classes and can help to present the written and spoken material, provide activities, promote interaction, serve as a reference on vocabulary and grammar, act as a source for classroom activities, serve as a syllabus, and offer self-access work or self-directed learning. Richards and Rodgers (2002, p. 30) suggest that the main aim of materials is to present and practice content, ease interaction between students, and promote learner autonomy. However, as Hutchinson and Waters (1989) argue, the primary role of materials is to facilitate the learning process because useful materials do not teach rather they encourage learning. Hedge (2002, p. 36) maintains that good materials allow the learners to prepare in advance by offering a grammatical and functional framework that provide for their common needs and wants. Mainly, materials provide students with the main source of contact with the language, the content of lessons, the balance of skills taught, and the type of practice learners participate in (Richards, 2007, p. 252). Finally, Harmer (2002, p. 304) assumes that coursebooks foster students' perception of progress, provide materials for revision, and engage them in multiple ways.

\subsection{Coursebook Evaluation}

The major material commonly used in ELT classrooms is the coursebook. Murphy $(1985$, p. 12) states that materials should be evaluated "in the light of current needs" and objectives. Therefore, material evaluation should be the top priority of any curriculum. Hutchinson and Waters $(1989$, p. 96) argue that material evaluation should be carried out in order to judge the fitness of our materials to our "particular purpose." They insist that all the variables need to be evaluated systematically in order to "save a lot of expense and frustration" (ibid, p. 96). Meanwhile, Alderson and Beretta (1996, p. 248-9) caution against a "deterministic" approach to evaluation and suggest taking a flexible procedure. Mukundan (2006, p. 175) believes that the major focus of evaluation should be on "the expected language learning outcomes" which results from using the materials. However good the materials are, they can hardly cater to and satisfy different students with different needs, objectives, wants, learning styles, attitudes, aptitudes, and cultural norms (Tomlinson, 2006, p. 1). This is because each individual student thinks, feels, and believes in divergent ways apart from the identical culture to which they belong. The reason that coursebooks need to be evaluated is that they might be suitable and ideal in a particular situation and with some particular students but they might turn out to be unuseful in a different situation (Richards, 2007, p. 256).

\subsection{Teachers as Coursebook Developers and Evaluators}

Although our main job is to engage students with "material which is relevant and engaging" (Harmer, 2002, p. 39), we also need to familiarize ourselves with material development and evaluation. On the other hand, the available material "can serve as a support for less experienced teachers who have yet to gain in confidence" (Cunningsworth, 1995 , p. 7). However, when teachers are pressed for time to develop their own coursebook, they can evaluate the available ones and use them "which they can have confidence in" (Harmer, 2002, p. 304). Masuhara (2006) believes that material development can help teachers to develop professionally. They can become more creative, effective, and critical in their teaching methods and can better help their students to learn effectively. In this way, they can make learning and teaching process "more fun, refreshing, and worthwhile" (ibid, p. 40). Coursebook development can help teachers to try to know their students, their needs, wants, and goals. It can help teachers to try to familiarize themselves with teaching and learning theories and their application in the classroom. In this way, teachers can discover their own potential, limits, and abilities in imparting knowledge and consequently gaining confidence in their skills. However, many teachers are hardly provided with enough time to carry out material research or develop their own materials (Gatehouse, 2001). Moreover, most of the teachers have no training in material evaluation so that are reluctant to undertake their own interpretations and evaluations. However, Murphy $(1985$, p. 12) insists that 
all the teachers need to learn to carry out material evaluation because "it is not a task that can be left to specialists alone if language teaching is to develop." The point to ponder is that if we want to have ideal coursebooks, we need "feedback from both teachers and students" in order to achieve our objectives and help students to learn effectively (Jordan, 1997, p. 138). The reason that teachers need to evaluate materials is to check their suitability for their students' needs, objectives, and wants as well as "their own teaching styles" (Richards, 2007, p. 270). Unlike Hutchinson and Waters (1987) who think that material writing is time-consuming and difficult, Jordan (1997, p. 260) is in favor of material production by teachers. He holds that material development can help contextualization: to make sure that they are relevant, interesting, and up-to-date. Meanwhile, in producing materials, teachers need to provide variety and sequence, grade activities based on the students' level, and finally present materials in a systematic and organized way (Dudley-Evans \& St John, 2000, p. 176). In order to write useful materials, Hutchinson and Waters $(1987$, p. 126) suggest that we need to make use of available materials to obtain ideas, work in a team, edit and revise our writings several times, have enough time available, and consider the appearance of materials. More importantly, Cunningsworth (1995, p. 10) insists that teachers should not rely too much on coursebooks because books reduce their flexibility and impede their contributions, creativity, and innovation. However, some of the NNS teachers are forced to depend heavily on coursebooks and this stifles their creativity and contribution in implementing various classroom activities.

\subsection{Coursebook Development}

Coursebook writing is a daunting and great undertaking. In order to develop a coursebook, first of all, we need to determine the "objectives" and why it is needed (Sadeghi, 2005, p. 29). Then, after clarifying goals, we need to carry out "needs analysis" in order to specify in detail what and how the material should be written, graded, and sequenced (Farhady, 2005, p. 80). Jordan (1997, p. 264) suggests that there are a number of variables to be considered in materials writing: "students, teachers, syllabus, methodology, resources, time, and finance." First of all, we need to gather enough information about the students: their levels, age, learning styles and strategies, cultural and social background, needs, wants, objectives, and preferences. We also need to obtain information about the teachers who intend to teach the coursebook that is going to be written: their skills, proficiency, abilities, experience, and their teaching conditions and resources. Also, we need to determine what type of content should be included: topics, themes, language skills, texts, tasks, exercises, vocabulary, grammar, study skills, dialogues, and general or specific texts. Masuhara (2006, p. 43) contends that "effective materials cannot be made without valid use of visuals ..." Meanwhile, Cunningsworth (1995, p. 103) argues that using visuals "provides meaningful contexts" which consequently enhances language learning. At this juncture, Harmer (2002, p. 45) believes that students should be exposed to different types and levels of texts "not only in terms of complexity, but also in range of genre and length." However, it is important to note that each subject and discipline "has its own specific language requirements" (McDonough, 1984, p. 12). Hutchinson and Waters (1987, p. 256) hold that the text types that are used "should be naturally occurring piece of communication" in order to generate "useful classroom activities." Some of the common features that coursebooks should have are as follows: authentic texts, comprehension checks/questions, summarizing, writing tasks, pair work, group discussions, listening activities, note-taking, and glossary of specialist terms" (Jordan, 1997, p. 256). Hedge (2002, p. 359) argues that it is better coursebooks to be supplemented with "drama, extensive reading, role-play, communication games and debates." Therefore, the supplementary activities can trigger interaction and negotiation of meaning in the language classroom among the students and provide opportunities for them to use their acquired vocabulary and grammar. In order to develop practice material, coursebook writers can use several sources to obtain them: students' language difficulties, feedback from classroom observation, and checking of comprehension (Jordan, 1997, p. 261). More importantly, the developed materials need to be graded and sequenced based on the following criteria: "simple to complex and need" (Richards, 2007, p. 150). The main issue that needs to be considered in coursebook writing is between the use of authentic and non-authentic texts and exercises. The problems surrounding non-authentic texts are that they hardly represent the real use of the language, and some texts lose their meaning and authenticity when they are simplified. On the other hand, the problems with authentic texts are their difficulty, and their inappropriateness to be used in language classes (Flowerdew \& Peacock, 2001, p. 182). However, the material writers can choose either authentic or non-authentic or both of them based on the students' proficiency level, needs, objectives, and interest. Meanwhile, sometimes the important factor is not the authenticity issue rather it is the authenticity or functional use of the language in meaningful contexts and situations. Another overarching point in coursebook development is team writing. Masuhara (2006, p. 43) is in favor of joint effort and states that working in groups can bestow "width and depth" to the materials, and different people with different talents can give support, feedback, motivation to each other. In this way, a lot of time can be saved, high level of quality can be achieved, and the group can check the material regularly. However, some problems might arise in team writing, such as deadline ignorance by some writers, differences of opinions, and personality clashes (Jordan, 1997, p. 261). There are also some main drawbacks in coursebook writing. For instance, Hutchinson and Waters (1987, p. 106-7) mention that some of the publishers 
are reluctant to produce books "for very limited markets." Meanwhile, Jordan (1997, p. 269) refers to shortage of time, insufficient money, and lack of cooperation.

\subsection{Coursebook Evaluation Methods}

Materials, especially coursebooks, need to be evaluated at every stage of the course in order to find their weaknesses and improve them. Hutchinson and Waters (1987, p. 97-8) believe that evaluation is a process of "matching needs to available solutions" and divide it into four steps: "defining criteria, subjective analysis, objective analysis, and matching." However, Robinson (1991, p. 59) proposes three types of material evaluation: "preliminary, summative, and formative." She states that preliminary evaluation takes place before the course begins and a checklist can be used to evaluate or select a coursebook. Summative evaluation is performed at the end of the course and investigates whether the coursebook is effective or has any deficiencies. Formative evaluation is carried out during the lifetime of the course and the weaknesses are identified and possible modifications are made. McDonough and Shaw (1993, cited in Jordan, 1997, p. 138) mention two types of evaluation: external evaluation (investigating cover, table of contents, and introduction) and internal evaluation (investigating every aspect in detail). Similarly, Cunningsworth and Kusel (1991, cited in Jordan, 1997, p. 138) list two types of evaluation: global appraisal (an impressionistic approach) and detailed evaluation (close examination of each unit of a book). As Mukundan (2006, p. 170) contends, traditionally, coursebooks were evaluated "impressionistically or used a checklist." However, he believes that a checklist only provides partial information and suggests combining a checklist with two other tools: concordance software and reflective journal. At this juncture, Harmer (2002, p. 301) emphasizes "to include student opinion and comment." It is believed that three overarching methods of evaluating a coursebook consist of administering questionnaire both to students and teachers, using tests not for assessing students but for evaluating coursebook units, and finally interviewing both students and teachers (Robinson, 1991, p. 60). More importantly, Sadeghi (2005, p. 30) insists on piloting coursebooks and teaching them for one semester in order to examine their virtues and weaknesses. In this vein, the best information about a coursebook can be obtained "in the light of classroom use" (Hutchinson and Waters, 1987, p. 125-6). However, evaluation based on a checklist has lost its credibility and teachers can make a professional judgment backed up by their practical experience (Cunningsworth, 1995). Apparently, most of the checklists are prepared in haste and their reliability is questionable. Also, Mukundan (2006, p. 171-2) refers to some of the shortcomings of checklists such as: the complexities of teaching-learning process cannot be evaluated by a checklist, some checklists include difficult and misleading terms, and some checklists contain complex and long-winded criteria. Therefore, Harmer (2002, p. 301) maintains that teachers had better prepare a checklist based on their own particular situation considering their objectives, needs, and cultural and social norms.

\section{The Study}

The institutional context for this study was a major state-run university (The University of Tabriz) with a student body of about 12,000 students, in the city of Tabriz, Iran. The University of Tabriz is a prestigious institution in the city of Tabriz and competition for entering this university is quite tough. It is because in order to enter a university in Iran, students have to take the University Entrance Examination each year. If they obtained good scores, they could be accepted to high ranking universities; otherwise they have to study at other low level institutions. Each academic year about 2500 undergraduate students enter The University of Tabriz. Table 1 below illustrates the type of core EAP courses that the students have to take and pass at The University of Tabriz.

The coursebook under study (Reading English in Action) was developed for the EGP course. The EGP which is a 3-hour-a-week course is only offered during one semester. This course is taught by language professors and English Department is responsible for coordinating it. Therefore, since the objective of EGP course is developing reading skills and strategies, this coursebook was prepared to meet the students' needs. This coursebook consisting of twenty units deals with different general topics such as global warming, sport, deforestation, Christmas celebrations, marriage, health, nutrition, etc. Each unit consists of a reading passage followed by various exercises and activities. The major purpose of this coursebook is to increase the students' vocabulary domain and enhance their grammar. It attempts to prepare the students to tackle their discipline's different requirements and fulfill their general needs on reading.

\section{Method}

\subsection{Participants}

Table 2 below indicates the background information of the students at the University of Tabriz. Also, table 3 below illustrates the background information of the language professors at the University of Tabriz.

As tables 2 and 3 depicts, this study comprised two groups: undergraduate students $(n=480)$ and language professors $(n=6)$. Altogether, the University of Tabriz consists of twelve faculties. Therefore, it was attempted to select the participants through stratified random sampling. In order to choose a representative sample, forty students were selected from each faculty: twenty male and twenty female (i.e. $40 \times 12=480$ ). The second group of the 
study's participants was the language professors who had taught the coursebook under study (Reading English in Action) for one semester. They had used it in their EGP classes and somehow knew its merits and demerits.

\subsection{Instruments}

The instruments in this study consisted of questionnaires and interviews.

\subsubsection{Questionnaires}

The questionnaire items were in the form of five-point Likert scale: strongly disagree $(S D=1)$, disagree $(D=2)$, unsure $(U=3)$, agree $(A=4)$, and strongly agree $(S A=5)$. The questionnaires were distributed by the researcher to the students and professors. They consisted of twenty one closed-ended and one open-ended item. The open-ended item was intended to elicit the students' and professors' overall opinions regarding the coursebook (Reading English in Action) and how it could be improved in order to fulfill the students' and course's goals. The closed-ended items focused on the virtues and weaknesses of the reading passages and their exercises and activities. The closed-ended items were posed in a way to investigate the following areas: vocabulary items, grammar exercises, cultural and social aspects, variety of topics and exercises, promotion of communicative activities, enhancing discussion, difficulty level for the students, layout and design of the book, and effectiveness of the exercises and activities. The following items represent in detail the type of questionnaire that was administered to the students $(n=480)$ and language professors $(\mathrm{n}=6)$.

1- The objectives of the coursebook (Reading English in Action) match the course's goals.

2- The objectives of the coursebook correspond to the students' aims.

3- The coursebook contains various types of reading passages.

4- The reading passages are culturally and socially appropriate.

5- The reading passages are interesting and up-to-date.

6- The topics generate discussion and argument.

7- The topics are authentic enough to arouse student interest.

8- The coursebook can meet and enhance the students' reading skills and strategies.

9- The coursebook contains useful and everyday vocabulary items.

10- The coursebook is effective in increasing the students' vocabulary domain.

11- Different types of grammatical structures are presented through different exercises and activities.

12- The primary function of the grammatical structures is to promote communicative activities.

13- The amount of the exercises and activities are sufficient.

14- The exercises and activities are interesting.

15- The exercises and activities are at the right level for the students.

16- The exercises and activities are efficient.

17- The exercises and activities engage the students in thinking about and using the language.

18- The activities stimulate cognitive rather than mechanical processes.

19- The instructions to the exercises and activities are clear.

20- The coursebook fosters independent language learning.

21- The layout and design is appropriate and student-friendly.

\subsubsection{Interviews}

In order to back up the questionnaire items and triangulate the data, semi-structured interviews were conducted with a selected number of students $(n=24)$ and all the language professors $(n=6)$ who filled in the questionnaire. The reason for carrying out the interview was to talk directly to the students and professors in order to investigate their opinions regarding the coursebook (Reading English in Action). The interview questions consisted of both general and detailed items about the coursebook. It was tried not to stick solely to the interview questions in order to allow the interviewees to open up and speak their mind and express what they genuinely thought about the coursebook. The interview items were built around the following issues:

- What are the virtues and weaknesses of the coursebook (Reading English in Action)?

- How can it be improved and revised? 
- What are the areas that need to be omitted and the areas that need to add other contents?

- How can we integrate the four language skills?

- How can we make the units more student-friendly?

- How can we enhance the learning process?

- How can we grade, sequence and present the contents?

\subsection{Data Collection}

The questionnaires were distributed by the researcher himself during four semesters. As it was mentioned earlier, the University of Tabriz consists of twelve faculties. Therefore, since the researcher had taught the EGP course at all the twelve faculties, the questionnaires were administered personally at the end of each semester (group administered questionnaire, Brown, 2001, p. 6). It was reasoned that the students had experienced the whole twelve units of the coursebook (Reading English in Action) and were rather familiar with its advantageous and disadvantageous. It usually took thirty minutes to answer the twenty one closed-ended items and fifteen minutes were dedicated to answering the last open-ended item. The students were usually asked to answer the open-ended item either in English or the Persian language. Before distributing the questionnaires, it was explained that the results of the questionnaires had no effect on their final grades and they were free not to answer them. Altogether, about 480 students (240 male and 240 female) answered the questionnaires. However, the professors' questionnaires were sent through email. Meanwhile, twenty four students (12 male and 12 female) were selected through stratified random sampling for the interview. That is, from each of the twelve faculties, two students (one male and one female) were chosen to be interviewed. The interviews with the students were conducted at the researcher's office. In order to put the students at ease, they were interviewed in the Persian language. The professors were interviewed separately at their offices. Also, in order to create a friendly and intimate situation, the interviews with the professors were carried out in their mother tongue.

\subsection{Data Analysis}

The questionnaire data were analyzed through SPSS. However, the interview data were analyzed manually. In order to analyze the interview data, the obtained information was organized based on relevant themes and topics, then, the intended themes were separated and reduced and the emerging new themes were deducted (Blaxter et al., 2006). After that, the students' and professors' answers were compared and contrasted with the questionnaire data.

\section{Results and Discussions}

Table 4 below illustrates the results of the students' and professors' answers to the questionnaire.

Table 4 on the results of students' and professors' responses to the questionnaire items indicates that they are rather similar in most cases. There are only a few minor differences of opinion between the students' and professors' answers. Concerning item no.1, while all the professors (100\%) believe that the coursebook (Reading English in Action) goals match the course objectives, only $75 \%$ of the students agree with it. The second small difference relates to item no.3. While the mean on the variety of reading passages for professors is 3.66 , it is 4 for the students. Regarding the usefulness of the vocabulary items included in the coursebook, all the professors $(100 \%)$ contend that they are worthwhile, but only $87.7 \%$ of students agree with it. The other minute difference relates to item no.10. While all the professors $(100 \%)$ state that the coursebook can increase the students' vocabulary domain, only $87 \%$ of students agree with it. Another very small difference is related to item no.13. While the mean on the amount of exercises and activities for professors is 4.16 , it is 3.9 for the students. With regard to item no.14, while all the professors (100\%) contend that the exercises and activities are interesting, only $88.4 \%$ of the students agree with it. Concerning item no.15, all the professors (100\%) affirm that the exercises and activities are at the right level for the students, however, only $87.8 \%$ of the students agree with it. With regard to item no.16 on the efficiency of exercises and activities, the mean for professors is 4.66 , but for students it is only 3.8. The last very minute difference is concerned with item no.19 on the clarity of the instructions. While the mean for professors is 5 , it is 4.17 for the students. However, if we closely compare the students' and professors' answers, we notice that the differences barely exceed $12 \%$. Meanwhile, the overall average mean for students is 3.76 and for professors it is 3.93 , which are very close. This indicates that the students' and professors' opinions are similar regarding the usefulness of the developed coursebook (Reading English in Action) on enhancing the students' reading ability. Overall, the results of the questionnaire imply that the coursebook under study is useful and helpful in contributing to reading skill and boosting the students' vocabulary domain.

However, the results of intimate semi-structured interview with the students and professors suggest that the former expect more from the EGP (English for General Purposes) course which is offered to them. As it was noted earlier, the major objective of the EGP course at the University of Tabriz is to promote the reading skill. This course is 
offered throughout the Iranian universities in order to augment the students' reading skills and strategies. It is intended to prepare them to fulfill their university discipline's requirements. However, the following interview with one of the language professors reveals that some of the students expect more than reading skill from the EGP course.

Well, I should say that students nowadays want to develop not only their reading skills and strategies, but also they intend to improve their writing, speaking, and listening skills too. Since the EGP course can't meet their varied wants, they get distrustful and develop negative feelings about it. I assume their pessimistic view is more towards the course rather than the coursebook. They believe that the EGP course is unable to improve their general English and help them to tackle their educational and occupational needs. (Professor No.4)

In Iranian universities, the EGP course is only offered during one semester and it is studied for three hours a week in only seventeen weeks. Therefore, because of the short space of time, the coursebook (Reading English in Action) was dedicated mostly to improving the students' reading skill. But it seems that the students get bored with reading and become resentful towards the EGP course. In the following interview, one of the students expresses his opinion about the coursebook.

Overall, I have no objection to this coursebook, because it contains interesting reading passages and exercises. During this semester my reading has improved a lot. But I think it is better to have other types of activities, like free discussions. Most of the students prefer to speak and communicate in English language, but every session we have to read and do exercises without any change. Our professor emphasized that we should cover and finish all the twenty units. But it was a little boring, because the same things happened every session without any diversity. (Student No.23)

As the above interview with one of the students shows, most of the professors depend too much on the coursebook and do not create any variety in the classroom activities. For this reason most of the students develop negative feelings about the EGP course. Therefore, it seems logical that the professors use the coursebook as a stimulus to present and practice not only reading skill but also other skills too. Too much reliance on the coursebook brings about monotony and impedes creativity. More importantly, in the following interview with one of the professors, we notice one of the main drawbacks of the present coursebook (Reading English in Action) which is lack of visuals.

Well, I suppose that Reading English in Action lacks any visuals or drawings. It would have been better if it included some funny or real pictures. The plain texts, exercises and activities are sometimes boring for the students. But the layout, design and format of this book are good. The fonts that are used are not too small to tire the students; they are big enough to be appealing to the students and professors. Also, I should say that the quality of the paper that is used is excellent. (Professor No.5)

It should be acknowledged that one of the main disadvantageous of this coursebook is the lack of visuals or drawings in it. It is known that images and pictures have tremendous impact on stimulating the learning process and hindering monotony (Cunningsworth, 1995). However, the main drawback for this was the cost. Including visuals required more space and consequently it could add to the overall cost of the book. At the same time, we (publisher and the writer) intended this coursebook to be affordable and all the students could be able to have and use it. However, we plan to include drawings and figures in the future revised edition of the coursebook. Another issue that was raised by one of the students was the lack of answer key. She remarked that without answer key she had to spend a lot of time on doing exercises at home and preparing herself for the class.

Our professor has required us to study a unit each week at home and to be ready at the class. So, we have to read the reading passages and do the exercises. I usually use a dictionary for reading passages and look up the new words. But it is sometimes difficult to do exercises because our coursebook does not have answer key. Also, I think it would have been better if our coursebook included a glossary of unfamiliar words. (Student No.18)

The reason that an answer key was not included was that some of the students can't be bothered to do the exercises and find the answers for themselves. They just copy the answers from answer key and do not use their mind to do them. For this reason, it was decided to push the students a little and challenge them to think and come up with their own solutions. However, the six professors who taught the coursebook at the University of Tabriz were provided with the answer key. Meanwhile, the reason that a glossary was not included was that some of the students only rely on it and do not try to buy and use a dictionary. It is very important that each student to have a monolingual dictionary (English to English) and learn the meaning of words, their use, and their parts of speech (verb, noun, etc).

\section{Conclusion and Implications}

Writing a coursebook is indeed a challenging and daunting task. It requires a lot of time, energy, and experience for the writer and investment for the publisher. The main obstacle for the present researcher was to find a publisher to publish the coursebook because most of the publishers in our city (Tabriz) were not willing to invest a lot of money 
on producing an unknown book. In this article the coursebook Reading English in Action was presented and evaluated. As Tomlinson (2006) notes, there is no perfect coursebook, because each coursebook is used in different situation by different students who have different objectives, needs, wants, proficiency level, and cultural background. Therefore, it is very rare that a coursebook could satisfy all the different tastes whether students or teachers. However, every coursebook needs to be evaluated from time to time in order to pin point its deficiencies and improve them. In this research we tried to evaluate the Reading English in Action through questionnaires, interviews, and feedback from classroom use. Meanwhile, the researcher himself had taught the book for four semesters and knew its virtues and weaknesses. As it is clear, we did not use a checklist to evaluate this coursebook. It is because each coursebook is written for some special and intended purposes and there is hardly any such perfect checklist for evaluation. Therefore, we tried to develop a questionnaire based on the objectives of the Reading English in Action. As Harmer (2002) emphasizes, it is wrong to use checklists developed by other researchers. We need to develop our own checklist based on local needs, objectives, and resources. All in all, useful insights were gained from the evaluation process. Therefore, the constructive comments that were provided by the students and professors at the University of Tabriz, and the researcher's own experience in teaching this book for four semesters would help to revise and improve it. As Masuhara (2006) suggests, material writing is an invaluable process for teacher development. Developing the present coursebook was an eye-opener experience for the researcher which at the same time bestowed him confidence and made him feel empowered. Therefore, it would be attempted to apply the in-use and post-use feedback and views expressed by the students and professors in the new editions of the Reading English in Action. Based on recommendations made by Tomlinson (2006) it would be tried to use more localized texts. An attempt would be made to infuse the three language skills in addition to the reading and follow an integrative approach to the EGP (English for General Purposes) course. In this way, the students would be motivated to pay more attention and treat the EGP course more seriously and diligently. Also, more interactive tasks would be added to the coursebook because most of the students prefer communicative activities. Meanwhile, some drawings, figures, and images would be added to this book in order to arouse the students' interest and stimulate them for more intimate learning. It is important to note that even though I had developed the book I had no idea whether or not it was useful. It was, however, after four semesters' use in the classroom that I came to know its merits and limitations. Therefore, it is quite simplistic to assume that we can find a checklist and evaluate a book before using it in the classroom, i. e. pre-use instead of in-use or post-use. A checklist might be useful only after classroom use. It is because evaluating a book based on a checklist is a mechanical and abstract approach (Mukundan, 2006).

The information gained from this study could be worthwhile for material writers, coursebook designers, curriculum developers, teachers, and postgraduate students. The main experience that the researcher obtained after publishing this book was that it is very important that before we publish a book, we should ask two or more teachers to read it and comment on it and ideally teach it at least for one semester. It is because there might be some points that the coursebook writer may not know or forget about them totally. Meanwhile, it is necessary that after publishing a coursebook we ask two or more teachers to teach it and provide us with their views and comments. In this way, we can improve the deficiencies and produce a useful and quality coursebook in the future.

\section{References}

Alderson, J. C. \& Beretta, A. (Eds.). (1996). Evaluating second language education. Second printing. Cambridge: Cambridge University Press.

Blaxter, L., Hughes, C. \& Tight, M. (2006). How to research. Berkshire: Open University Press.

Brown, J. D. (2001). Using surveys in language programs. Cambridge: Cambridge University Press.

Cunningsworth, A. (1995). Choosing your coursebook. Oxford: Heinemann.

Dudley-Evans, T. \& St John, M. J. (2000). Developments in English for specific purposes: A multidisciplinary approach. Cambridge: Cambridge University Press.

Farhady, H. (2005). Reflections on and directions for ESP materials development. In G. R. Kiany \& M. Khayamdar (Eds.). Proceedings of the First National ESP/EAP Conference, Vol.3, (pp.2-32). Tehran: SAMT.

Flowerdew, J. \& Peacock, M. (2001). The EAP curriculum: issues, methods, and challenges. In J. Flowerdew \& M. Peacock (Eds.). Research perspectives on English for academic purposes. (pp. 177-194). Cambridge: Cambridge University Press.

Gatehouse, K. (2001). Key issues in English for specific purposes (ESP) curriculum development. The Internet TESL Journal 7(10) (online). http://iteslj.org/articles/gatehouse-ESP.html (9 July 2007).

Harmer, J. (2002). The practice of English language teaching. Second ed. London: Longman.

Hedge, T. (2002). Teaching and learning in the language classroom. Third ed. Oxford: Oxford University Press. 
Hutchinson, T. \& Waters, A. (1987). English for specific purposes: a learning-centered approach. Tenth ed. Cambridge: Cambridge University Press.

Jordan, R. R. (1997). English for academic purposes: A guide and resource book for teachers. Cambridge: Cambridge University Press.

Masuhara, H. (2006). Materials as a teacher development tool. In J. Mukundan (Ed.), Readings on ELT materials II. (pp. 34-46). Malaysia: Pearson Longman.

McDonough, J. (1984). ESP in perspective: A practical guide. London: Collins ELT.

Mukundan, J. (2006). Are there new ways of evaluating ELT textbooks? In J. Mukundan (Ed.), Readings on ELT materials II. (pp. 170-180). Malaysia: Pearson Longman.

Murphy, D. F. (1985). Evaluation in language teaching: Assessment, accountability and awareness. In J. C. Alderson (Ed.), Evaluation. (pp. 1-17). Oxford: Pergamon.

Richards, J. C. (2007). Curriculum development in language teaching. Eighth printing. New York: Longman.

Richards, J. C. \& Rodgers, T. S. (2002). Approaches and methods in language teaching. Second ed. Cambridge: Cambridge University Press.

Robinson, P. C. (1991). ESP today: A practitioner's guide. New York: Prentice Hall.

Sadeghi, A. R. (2005). ESP methodology: A transition from the present state. In G. R. Kiany \& M. Khayamdar (Eds.). Proceedings of the First National ESP/EAP Conference, Vol.2, (pp.21-33). Tehran: SAMT.

Tomlinson, B. (2006). Localizing the global: Matching materials to the context of learning. In J. Mukundan (Ed.), Readings on ELT materials II. (pp. 1-16). Malaysia: Pearson Longman.

Zohrabi, M. (2005). Reading English in action. Second Printing. Tabriz: Mehr Iman Publications.

Table 1. The EAP courses offered at the University of Tabriz

\begin{tabular}{lccc}
\hline Title of the course & $\begin{array}{c}\text { No. of } \\
\text { credits }\end{array}$ & $\begin{array}{l}\text { Status of } \\
\text { course }\end{array}$ & $\begin{array}{r}\text { Time to } \\
\text { be offered }\end{array}$ \\
\hline $\begin{array}{l}\text { English for General Purposes (EGP) } \\
\text { English for Specific Purposes (ESP) }\end{array}$ & $2 / 4$ & $\begin{array}{c}\text { Compulsory } \\
\text { Compulsory }\end{array}$ & $\begin{array}{c}\text { First or second semester } \\
\text { Third semester onwards }\end{array}$ \\
\hline
\end{tabular}

Table 2. Background information of the students

\begin{tabular}{lccc}
\hline & & Frequency & Percent \\
\hline Gender & Male & 240 & 50 \\
& Female & 240 & 50 \\
& Total & 480 & 100 \\
Age & $18-19$ & 298 & 62 \\
& $20-21$ & 134 & 28 \\
& 22 -above & 48 & 10 \\
& Total & 480 & 100 \\
Faculty & Agriculture & 40 & \\
Chemistry & 40 & 8.4 \\
Civil Engineering & 40 & 8.4 \\
Educational Sciences \& Psychology & 40 & 8.4 \\
Electronics \& Computer Sciences & 40 & 8.4 \\
Humanities and Social Sciences & 40 & 8.4 \\
Mathematical sciences & 40 & 8.4 \\
Mechanical Engineering & 40 & 8.4 \\
Natural Sciences & 40 & 8.4 \\
Persian Literature\& Foreign Languages & 40 & 8.4 \\
Physics & 40 & 8.4 \\
Veterinary & \multicolumn{1}{c}{ Total } & 40 & 100 \\
\hline
\end{tabular}


Table 3. Background information of the language professors

\begin{tabular}{cccccc}
\hline No & Gender & Age & $\begin{array}{c}\text { Years of } \\
\text { experience }\end{array}$ & Qualifications & $\begin{array}{c}\text { Employment } \\
\text { status }\end{array}$ \\
\hline 1 & $\mathrm{M}$ & 59 & 25 & PhD & Full-time \\
2 & $\mathrm{M}$ & 46 & 15 & $\mathrm{PhD}$ & Full-time \\
3 & $\mathrm{M}$ & 57 & 28 & $\mathrm{MA}$ & Part-time \\
4 & $\mathrm{~F}$ & 36 & 16 & $\mathrm{PhD}$ & Full-time \\
5 & $\mathrm{~F}$ & 35 & 5 & $\mathrm{MA}$ & Full-time \\
6 & $\mathrm{~F}$ & 37 & 10 & & Part-time \\
\hline
\end{tabular}

Table 4. Students' and professors' answers to the questionnaire

\begin{tabular}{|c|c|c|c|c|c|c|c|c|c|c|c|c|}
\hline \multicolumn{7}{|c|}{ Students } & \multicolumn{6}{|c|}{ Professors } \\
\hline Item & SD & $\mathrm{D}$ & $\mathrm{U}$ & $\bar{A}$ & SA & $\mathrm{M}$ & SD & $\mathrm{D}$ & $\mathrm{U}$ & $\bar{A}$ & SA & $\mathrm{M}$ \\
\hline 1 & - & $\begin{array}{c}45 \\
9.45 \%\end{array}$ & $\begin{array}{c}75 \\
15.6 \%\end{array}$ & $\begin{array}{l}360 \\
75 \%\end{array}$ & - & 3.65 & - & - & - & $\begin{array}{c}1 \\
17 \%\end{array}$ & $\begin{array}{c}5 \\
83 \%\end{array}$ & 4.83 \\
\hline 2 & $\begin{array}{c}14 \\
3 \% \\
\end{array}$ & $\begin{array}{c}26 \\
5.4 \% \\
\end{array}$ & $\begin{array}{c}68 \\
14 \% \\
\end{array}$ & $\begin{array}{c}372 \\
77.5 \%\end{array}$ & - & 3.66 & - & $\begin{array}{c}2 \\
34 \% \\
\end{array}$ & $\begin{array}{c}2 \\
34 \% \\
\end{array}$ & $\begin{array}{c}2 \\
34 \% \\
\end{array}$ & - & 3 \\
\hline 3 & - & $\begin{array}{c}31 \\
6.4 \%\end{array}$ & $\begin{array}{c}42 \\
8.7 \%\end{array}$ & $\begin{array}{l}321 \\
67 \%\end{array}$ & $\begin{array}{c}86 \\
18 \%\end{array}$ & 4 & - & $\begin{array}{c}1 \\
17 \%\end{array}$ & - & - & $\begin{array}{c}5 \\
83 \%\end{array}$ & 3.66 \\
\hline 4 & $\begin{array}{l}9 \\
2 \\
\end{array}$ & $\begin{array}{c}75 \\
15.6 \%\end{array}$ & $\begin{array}{r}39 \\
8 \% \\
\end{array}$ & $\begin{array}{c}296 \\
61.6 \%\end{array}$ & $\begin{array}{c}61 \\
12.7 \%\end{array}$ & 3.67 & - & $\begin{array}{c}1 \\
17 \% \\
\end{array}$ & - & $\begin{array}{c}4 \\
66 \% \\
\end{array}$ & $\begin{array}{c}1 \\
17 \% \\
\end{array}$ & 3.83 \\
\hline 5 & $\begin{array}{c}7 \\
1.5 \% \\
\end{array}$ & $\begin{array}{c}79 \\
16.5 \% \\
\end{array}$ & $\begin{array}{l}29 \\
6 \% \\
\end{array}$ & $\begin{array}{l}298 \\
62 \% \\
\end{array}$ & $\begin{array}{c}67 \\
14 \% \\
\end{array}$ & 3.7 & - & $\begin{array}{c}1 \\
17 \% \\
\end{array}$ & - & $\begin{array}{c}4 \\
66 \% \\
\end{array}$ & $\begin{array}{c}1 \\
17 \% \\
\end{array}$ & 3.83 \\
\hline 6 & $\begin{array}{c}13 \\
2.7 \%\end{array}$ & $\begin{array}{c}43 \\
9 \%\end{array}$ & $\begin{array}{c}28 \\
5.8 \%\end{array}$ & $\begin{array}{c}301 \\
62.7 \%\end{array}$ & $\begin{array}{c}95 \\
20 \%\end{array}$ & 3.9 & - & $\begin{array}{c}2 \\
34 \%\end{array}$ & - & $\begin{array}{c}4 \\
66 \%\end{array}$ & - & 3.33 \\
\hline 7 & $\begin{array}{c}9 \\
2 \%\end{array}$ & $\begin{array}{l}29 \\
6 \%\end{array}$ & $\begin{array}{l}202 \\
42 \%\end{array}$ & $\begin{array}{c}221 \\
46 \%\end{array}$ & $\begin{array}{c}19 \\
4 \%\end{array}$ & 3.44 & - & $\begin{array}{c}1 \\
17 \%\end{array}$ & - & $\begin{array}{c}5 \\
83 \%\end{array}$ & - & 3.66 \\
\hline 8 & $\begin{array}{c}9 \\
2 \%\end{array}$ & $\begin{array}{c}37 \\
7.7 \%\end{array}$ & $\begin{array}{l}39 \\
8 \%\end{array}$ & $\begin{array}{c}389 \\
81 \%\end{array}$ & $\begin{array}{c}6 \\
1.2 \%\end{array}$ & 3.72 & - & - & $\begin{array}{c}1 \\
17 \%\end{array}$ & $\begin{array}{c}5 \\
83 \%\end{array}$ & - & 3.83 \\
\hline 9 & $\begin{array}{c}7 \\
1.5 \%\end{array}$ & $\begin{array}{c}36 \\
7.5 \% \\
\end{array}$ & $\begin{array}{c}16 \\
3.3 \%\end{array}$ & $\begin{array}{c}402 \\
83.7 \%\end{array}$ & $\begin{array}{c}19 \\
4 \%\end{array}$ & 3.81 & - & - & - & $\begin{array}{c}5 \\
83 \%\end{array}$ & $\begin{array}{c}1 \\
17 \%\end{array}$ & 4.16 \\
\hline 10 & $\begin{array}{c}7 \\
1.5 \%\end{array}$ & $\begin{array}{c}41 \\
8.5 \%\end{array}$ & $\begin{array}{c}14 \\
3 \%\end{array}$ & $\begin{array}{c}413 \\
86 \%\end{array}$ & $\begin{array}{c}5 \\
1 \%\end{array}$ & 3.76 & - & - & - & $\begin{array}{c}5 \\
83 \%\end{array}$ & $\begin{array}{c}1 \\
17 \%\end{array}$ & 4.16 \\
\hline 11 & $\begin{array}{c}5 \\
1 \% \\
\end{array}$ & $\begin{array}{c}9 \\
2 \%\end{array}$ & $\begin{array}{c}9 \\
2 \%\end{array}$ & $\begin{array}{c}42 \\
87.7 \%\end{array}$ & $\begin{array}{c}36 \\
7.5 \%\end{array}$ & 4 & - & - & - & $\begin{array}{c}6 \\
100 \%\end{array}$ & - & 4 \\
\hline 12 & $\begin{array}{c}4 \\
0.8 \%\end{array}$ & $\begin{array}{c}16 \\
3.3 \%\end{array}$ & $\begin{array}{c}59 \\
12.3 \%\end{array}$ & $\begin{array}{c}387 \\
80.6 \%\end{array}$ & $\begin{array}{c}14 \\
3 \%\end{array}$ & 3.81 & - & $\begin{array}{c}1 \\
17 \%\end{array}$ & $\begin{array}{c}2 \\
33 \%\end{array}$ & $\begin{array}{c}3 \\
50 \%\end{array}$ & - & 3.33 \\
\hline 13 & - & $\begin{array}{c}30 \\
6.2 \%\end{array}$ & $\begin{array}{c}4 \\
0.8 \%\end{array}$ & $\begin{array}{c}432 \\
90 \%\end{array}$ & $\begin{array}{c}14 \\
3 \%\end{array}$ & 3.9 & - & - & - & $\begin{array}{c}5 \\
83 \%\end{array}$ & $\begin{array}{c}1 \\
17 \%\end{array}$ & 4.16 \\
\hline 14 & $\begin{array}{c}4 \\
0.8 \%\end{array}$ & $\begin{array}{c}41 \\
8.5 \%\end{array}$ & $\begin{array}{c}11 \\
2.3 \%\end{array}$ & $\begin{array}{c}405 \\
84.4 \%\end{array}$ & $\begin{array}{c}19 \\
4 \%\end{array}$ & 3.82 & - & - & - & $\begin{array}{c}4 \\
66 \%\end{array}$ & $\begin{array}{c}2 \\
34 \% \\
\end{array}$ & 4.33 \\
\hline 15 & $\begin{array}{c}5 \\
1 \%\end{array}$ & $\begin{array}{l}29 \\
6 \%\end{array}$ & $\begin{array}{c}25 \\
5.2 \%\end{array}$ & $\begin{array}{c}410 \\
85.5 \%\end{array}$ & $\begin{array}{c}11 \\
2.3 \%\end{array}$ & 3.8 & - & - & - & $\begin{array}{c}3 \\
50 \%\end{array}$ & $\begin{array}{c}3 \\
50 \%\end{array}$ & 4.5 \\
\hline 16 & $\begin{array}{c}6 \\
1.2 \%\end{array}$ & $\begin{array}{c}25 \\
5.2 \%\end{array}$ & $\begin{array}{c}31 \\
6.5 \%\end{array}$ & $\begin{array}{c}411 \\
85.6 \%\end{array}$ & $\begin{array}{c}7 \\
1.5 \%\end{array}$ & 3.8 & - & - & - & $\begin{array}{c}2 \\
34 \%\end{array}$ & $\begin{array}{c}4 \\
66 \% \\
\end{array}$ & 4.66 \\
\hline 17 & $\begin{array}{c}7 \\
1.5 \%\end{array}$ & $\begin{array}{c}16 \\
3.3 \%\end{array}$ & $\begin{array}{c}61 \\
12.7 \%\end{array}$ & $\begin{array}{c}391 \\
81.5 \%\end{array}$ & $\begin{array}{c}5 \\
1 \%\end{array}$ & 3.77 & - & - & $\begin{array}{c}2 \\
34 \%\end{array}$ & $\begin{array}{c}4 \\
66 \%\end{array}$ & - & 3.66 \\
\hline 18 & $\begin{array}{c}10 \\
2 \%\end{array}$ & $\begin{array}{c}27 \\
5.6 \%\end{array}$ & $\begin{array}{c}78 \\
16.2 \%\end{array}$ & $\begin{array}{c}362 \\
75.5 \%\end{array}$ & $\begin{array}{c}3 \\
0.6 \%\end{array}$ & 3.66 & - & $\begin{array}{c}1 \\
17 \%\end{array}$ & $\begin{array}{c}1 \\
17 \%\end{array}$ & $\begin{array}{c}4 \\
66 \%\end{array}$ & - & 3.5 \\
\hline 19 & - & - & $\begin{array}{c}9 \\
2 \%\end{array}$ & $\begin{array}{c}380 \\
79 \% \\
\end{array}$ & $\begin{array}{c}91 \\
19 \%\end{array}$ & 4.17 & $\begin{array}{l}- \\
-\end{array}$ & - & - & - & $\begin{array}{c}6 \\
100 \%\end{array}$ & 5 \\
\hline 20 & $\begin{array}{c}7 \\
1.4 \%\end{array}$ & $\begin{array}{c}71 \\
15 \%\end{array}$ & $\begin{array}{c}92 \\
19 \%\end{array}$ & $\begin{array}{l}302 \\
63 \%\end{array}$ & $\begin{array}{c}8 \\
1.6 \%\end{array}$ & 3.5 & - & - & $\begin{array}{c}2 \\
34 \%\end{array}$ & $\begin{array}{c}4 \\
66 \%\end{array}$ & - & 3.66 \\
\hline 21 & $\begin{array}{c}14 \\
3 \%\end{array}$ & $\begin{array}{c}86 \\
18 \%\end{array}$ & $\begin{array}{c}102 \\
21 \%\end{array}$ & $\begin{array}{c}25 \% 9 \\
54\end{array}$ & $\begin{array}{r}19 \\
4 \%\end{array}$ & 3.4 & - & $\begin{array}{c}1 \\
17 \%\end{array}$ & $\begin{array}{c}1 \\
17 \%\end{array}$ & $\begin{array}{c}4 \\
66 \%\end{array}$ & - & 3.5 \\
\hline
\end{tabular}

Students' overall $\mathrm{SD}=0.18$ and Average mean $=3.76$

Professors' overall $\mathrm{SD}=0.52$ and Average mean $=3.93$ 